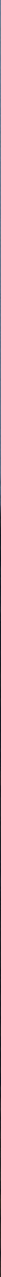

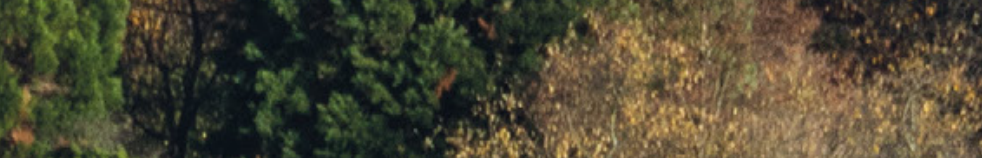

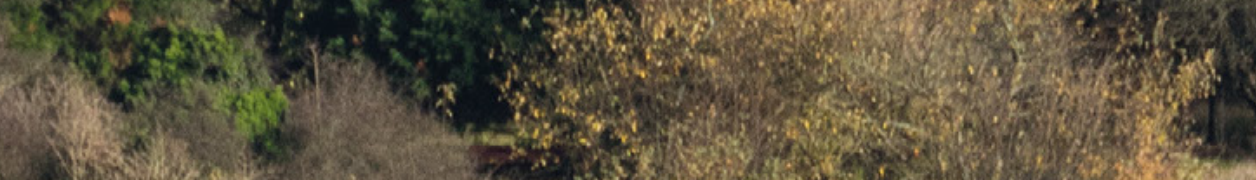

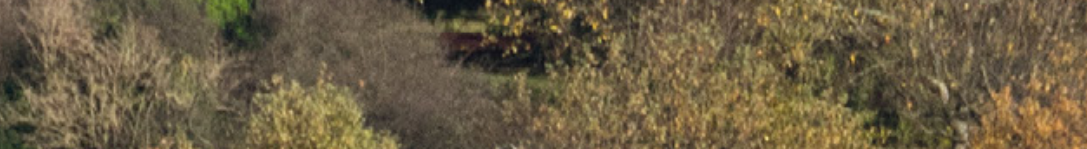

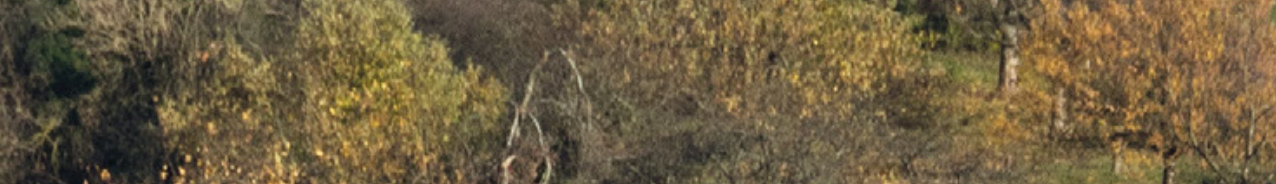

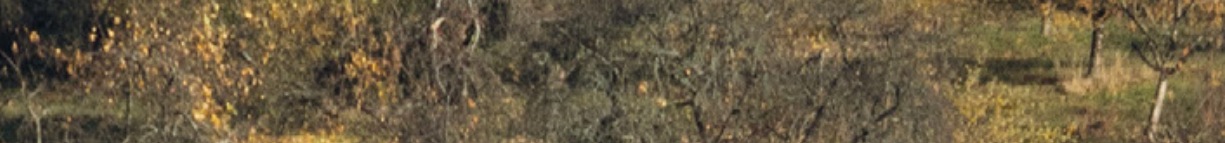

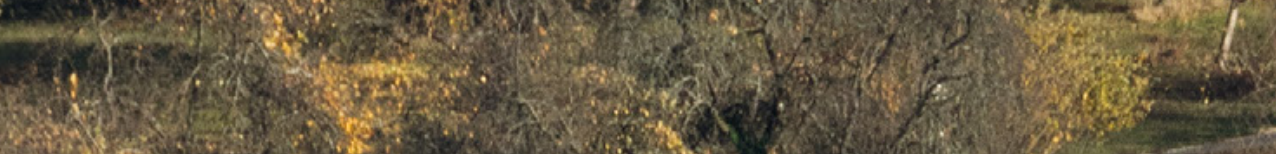
$x^{2}+3+7 x=$ $2 x^{2}$ (20.

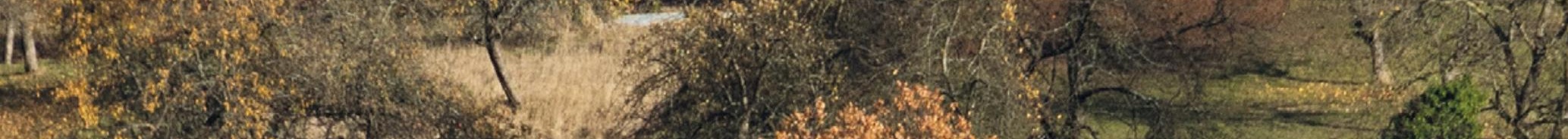

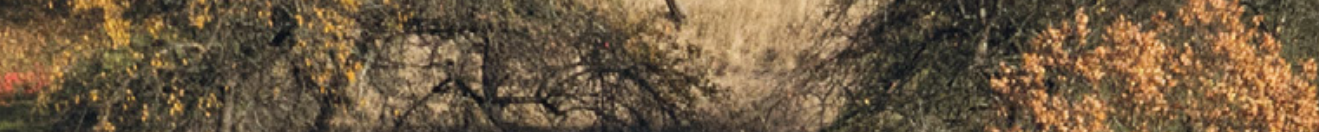

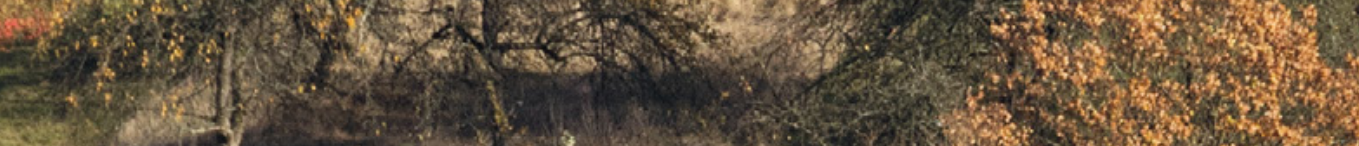

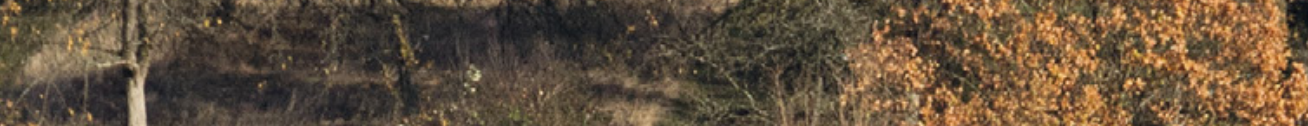

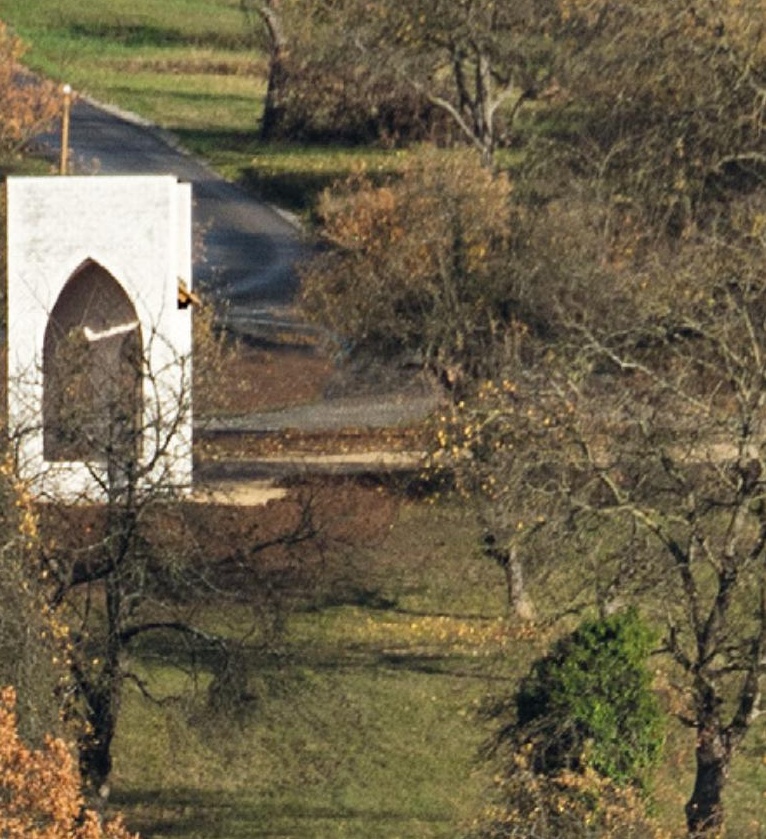
S- 


\title{
The Story of the Tower on the Rems,
} Plïderhausen

\author{
La Historia de la Torre de Rems, \\ Plïderhausen
}

\section{A História da Torre no Rems, Plïderhausen}

\section{Previous History}

It has been a bit longer than two years since Jórunn Ragnarsdóttir phoned to tell me about the project of 16 Stations for the Rems Valley Garden Show 2019. Quite spontaneously, and before being appraised of further details, I agreed to participate. An initial meeting took place in December of 2016, and the 16 invited architects were assigned 16 different towns and municipalities. Fortune matched me up with Plüderhausen. On the very same day, the mayor brought me to a meadow orchard above the town, pointed out a place that was situated in the midst of the trees, and identified it as the intended site. Hanging from the trees, I noticed scraps of paper bearing thickly-printed numbers. In response to my query, he proceeded to elucidate a Plüderhausen tradition...

\section{The Tradition}

Since the mid-1990s, every couple whose members say "I do" at Plüderhausen Town Hall plant a fruit tree on the so-called "Hochzeitswies" (nuptial meadow). The choices include apple, cherry, pear, and plum.

This revival by the community of an 'old custom' serves the preservation and cultivation of the cultural landscape, i.e. the fruit orchards of the Rems Valley. The custom was introduced after a drastic rupture in the everyday life of the region. After the Thirty Years' War,
Historia Previa

Han pasado algo más de dos años desde que Jórunn Ragnarsdóttir me llamó para hablarme sobre el proyecto de 16 estaciones para la Feria del Jardín del Valle de Rems en 2019. De manera espontánea y antes de valorar más detalles, acepté participar. En diciembre de 2016 tuvo lugar una primera reunión en la que a los 16 arquitectos invitados se les asignaron 16 ciudades y municipios diferentes. La fortuna me asignó Plüderhausen. Ese mismo día, el alcalde me llevó a un prado cerca de la ciudad, señaló un lugar que estaba situado en medio de los árboles y lo identificó como el sitio previsto. Colgando de los árboles, observé trozos de papel con gruesos números impresos; y, en respuesta a mi duda, procedió a dilucidar la tradición de Plüderhausen...

The Tradition

Desde mediados de la década de los 90, cada pareja que se decía el "Sí, quiero" en el ayuntamiento de Plüderhausen plantaba un árbol frutal en el llamado "Hochzeitswies" (prado nupcial). Las opciones incluían manzanos, cerezos, perales y ciruelos.

Este resurgimiento en la comunidad de una "vieja costumbre" favoreció la preservación y conservación del paisaje cultural, es decir, la huerta de frutales del Valle de Rems. La costumbre se introdujo después de un cambio drástico

\section{Uwe Schröder}


on both sides of streets and roads; tree vandals, meanwhile, were threatened with draconian punishments.

\section{The Design}

The purposeful arrangement and establishment of spaces at places is the task of architecture. Rising from the range of hills of the valley landscape of the Rems, above Plüderhausen, is a tower, which stands in the midst of a fruit orchard known as the "Hochzeitswiese". The so-called "Wedding Tower" marks out a place and founds the use of an architectural space. a los municipios y a los propietarios de terrenos privados se les animaba a plantar árboles frutales en ambos lados de las calles y los caminos; mientras tanto, se amenazó con castigos draconianos a todo aquel que vandalizara un árbol.

\section{El diseño}

La disposición intencionada y el diseño del espacio de cada lugar es tarea de la arquitectura. Asomando desde la hilera de colinas del paisaje del valle de Rems, sobre Plüderhausen, se erige una torre que destaca en el medio del huerto frutal conocido como el "Hochzeitswiese". La llamada "Torre de Bodas" designa un lugar e instaura el uso del espacio arquitectónico. pios e os proprietários de terrenos privados foram encorajados a plantar árvores de fruto em ambos os lados de ruas e estradas; aqueles que vandalizavam as árvores foram entretanto ameaçados com punições draconianas.

O Desenho

O arranjo e estabelecimento propositados de espaços nos locais é o papel da arquitectura. Uma torre ergue-se a partir das cadeias de colinas da paisagem do Vale do Rems, acima de Plüderhausen, encontrando-se no seio de um pomar conhecido como o "Hochzeitswiese". A chamada "Torre de Casamento" assinala um local e fundamenta o uso de espaço arquitectónico.

Plans and sections of the building | Plantas y secciones del edificio | Plantas e cortes do edifício
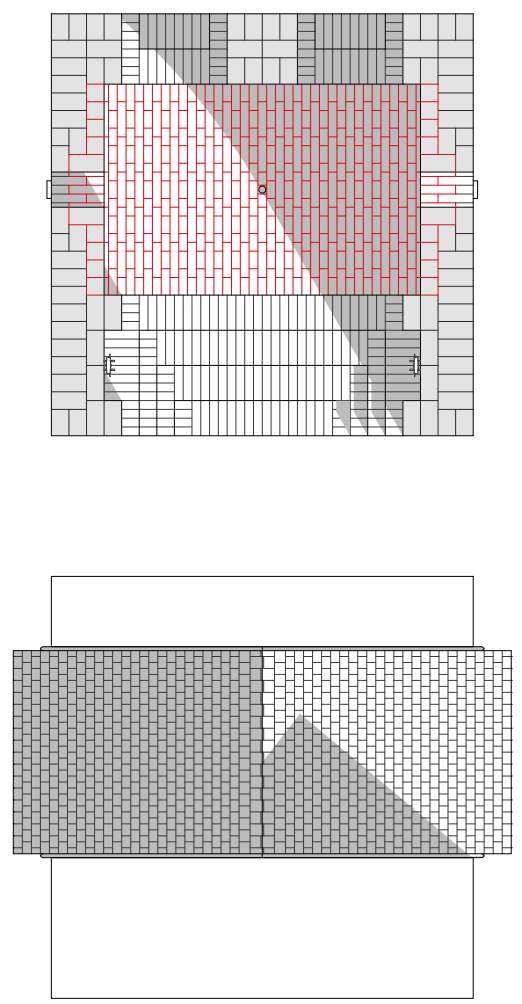

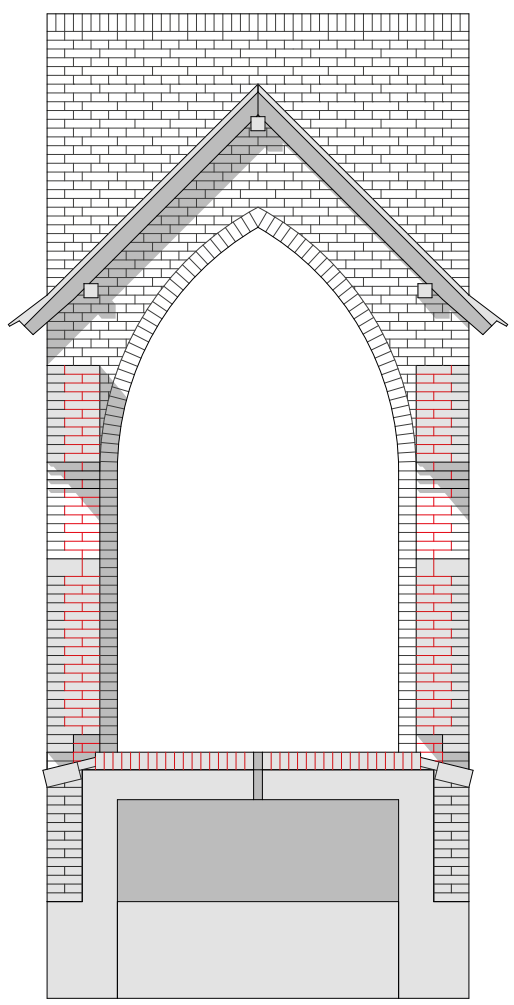

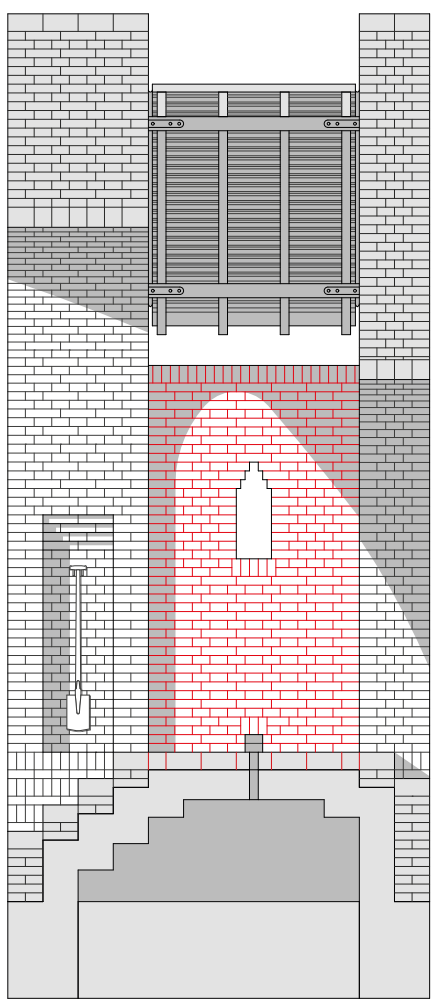



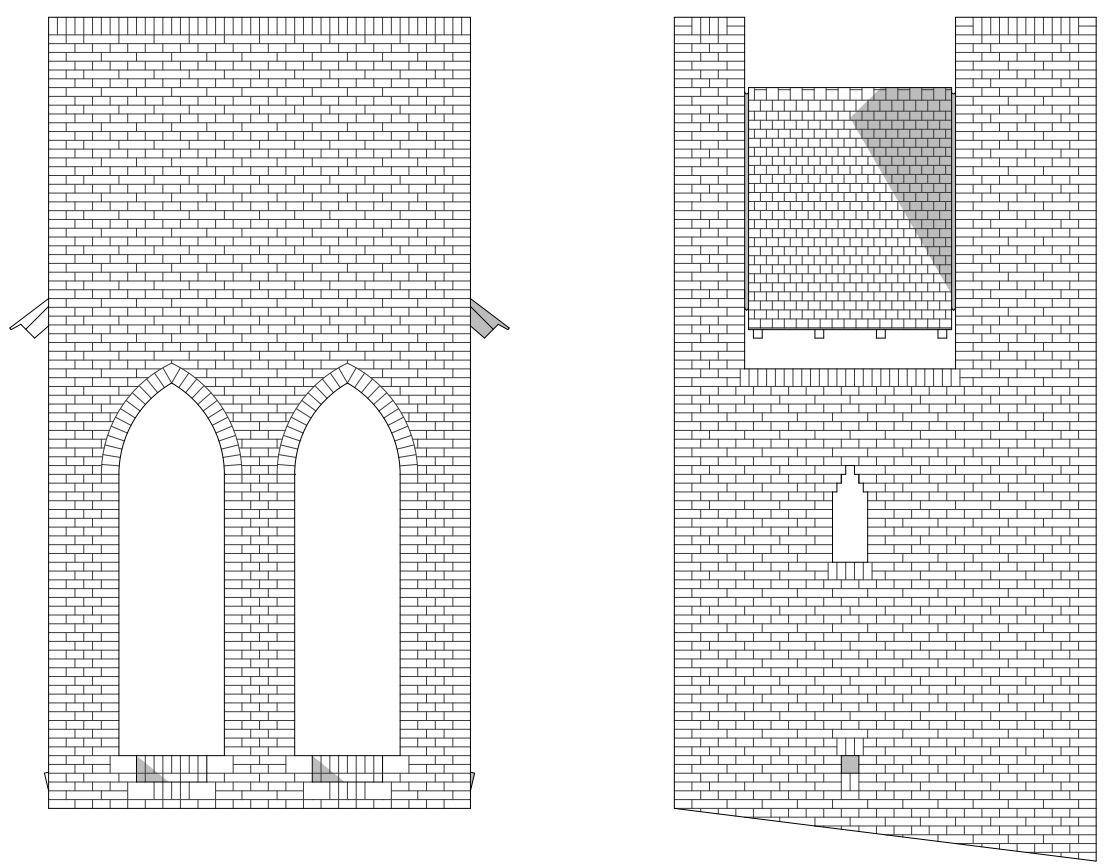

Elevations of the tower $\mid$ Alzados de la torre $\mid$ Alçados da torre

\section{Instruction Manual}

A meandering path leads the couple across the meadow beneath the crowns of the fruit trees and toward the tower. Above, they approach a white engobed brick tower, which displays a pair of narrow, parallel openings on the side that faces the rising slope. Via steps, the couple crosses the thresholds and enters the building together, albeit separated from one another by the two openings.

Within, in the tower's interior, the brick is divested of the white engobe and displays its red undersurface. For a moment, the two linger within the tower. Spread out in front of them and framed by a large arched opening is a view toward the west. Shimmering on the distant horizon is the large town, above which the sun sets. Further down, in the valley, the little town with its warped black roofs, from which the couple has come, and where they reside. For a moment, the two turn toward one another, assuring themselves

\section{Manual de Instrucciones}

Un camino serpenteante atraviesa el prado bajo las copas de los árboles frutales y se dirige hacia la torre. Por encima, la pareja se acerca a una torre de ladrillo blanco engobado, que muestra un par de aberturas estrechas y paralelas en el lado que da a la pendiente ascendente. Subiendo los escalones, la pareja cruza el umbral y entran juntos en el edificio, aunque separados entre sí por los dos huecos.

Dentro, en el interior de la torre, el ladrillo se despoja del engobe blanco y muestra su superficie interna roja. Por un momento, los dos permanecen dentro de la torre. Frente a ellos, y enmarcada por una gran abertura arqueada, aparece una vista hacia el oeste. Brillando en el horizonte lejano está la gran ciudad, sobre la cual se pone el sol. Más lejos, en el valle, la pequeña población con sus tejados negros deformados, desde donde viene la pareja, y donde reside.

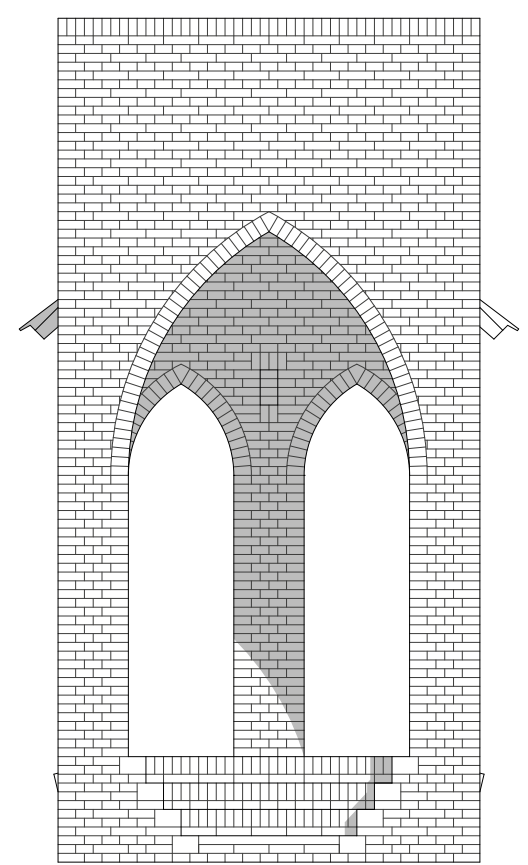

\section{Manual de instruções}

Um caminho tortuoso atravessa o prado abaixo das coroas das árvores de fruto e rumo à torre. Acima, eles aproximam-se de uma torre de tijolo branco engobado, que exibe um par de aberturas estreitas e paralelas do lado virado para a encosta ascendente. Subindo os degraus, o casal atravessa os umbrais e entra em simultâneo no edifício, embora separados um do outro pelas duas aberturas.

No interior da torre, o tijolo é despojado do engobe branco e exibe a cor vermelha da sua camada interior. Por um momento, os dois permanecem dentro da torre; espalhada à sua frente e enquadrada por uma abertura arqueada ampla, encontra-se a vista oeste; a cidade grande cintila no horizonte distante, acima do qual o sol se põe; mais abaixo, no vale, a pequena cidade com os seus telhados negros deformados, o casal veio onde residem; por um momento, viram-se um para o outro, assegurando-se quanto à promes- 


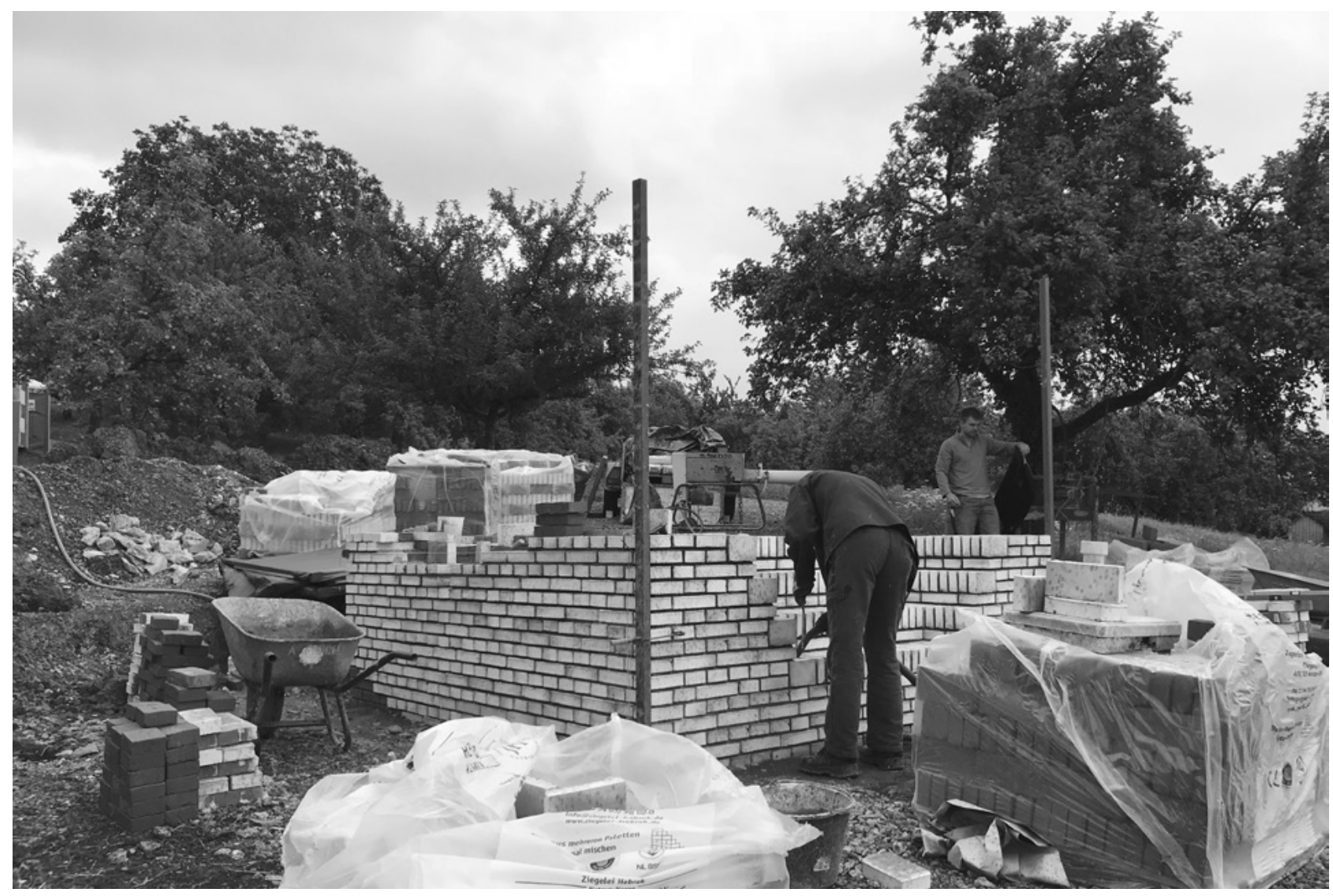

Building process. Laying the bricks | Proceso de construcción. Colocación de los ladrillos | Processo construtivo. Assentamento dos tijolos

of the promise they have given. A lucky coin falls through a dark slit in the red plastered floor. Arm in arm, hand in hand, the couple walks on together, passing through the deep threshold of the large arch, keeping track of the steps as they descend. Retrieving spades from the deep niches of the deep embrasures, they follow the meandering path that leads across the meadow beneath the crowns of the fruit trees and toward the intended location of their own tree.

\section{Romanticizing}

"The world must be romanticized. Thus one finds the original sense again. Romanticizing is nothing more than a qualitative involution. (...) When I give the commonplace a higher meaning, the customary a mysterious appearance, the known the dignity of the unknown, the finite the appearance of the infinite, I romanticize it" (Ameriks 2000: 227).
Por un instante, los dos se vuelven el uno hacia el otro, confirmando la promesa que se han hecho. Una moneda de la suerte cae por una hendidura oscura en el suelo rojo enyesado. Del brazo, de la mano, caminan juntos, pasando a través del umbral profundo del gran arco, siguiendo los escalones según bajan; recuperando las palas de los profundos nichos del alféizar, siguiendo el camino serpenteante que conduce al prado bajo las copas de los árboles frutales y hacia la ubicación prevista de su propio árbol.

Idealizando

"El mundo debe ser idealizado. Así uno encuentra el sentido original de nuevo. Idealizar no es más que una involución cualitativa. (... Cuando le doy a un lugar común un significado más elevado, a lo habitual una apariencia misteriosa, a lo conocido la dignidad de lo desconocido, a lo finito la apariencia de lo infinito, lo estoy idealizando" (Ameriks 2000: 227). sa que fizeram; uma moeda da sorte cai através de uma abertura escura no chão vermelho rebocado; de braço dado, de mão dada, o casal continua a andar, atravessando o umbral profundo do amplo arco, contando os passos à medida que desce; resgatando as pás dos nichos profundos nos vãos, eles seguem o trilho tortuoso que os leva através do pasto, por debaixo das coroas das árvores de fruto, rumo ao local pretendido para a sua árvore.

Romantizar

"O mundo precisa de ser romantizado. É assim que voltamos a encontrar o seu sentido original. Romantizar não é nada mais que uma involução qualitativa. (...) Quando eu dou ao banal um significado mais elevado, ao costumeiro uma aparência misteriosa, ao conhecido a dignidade do desconhecido, ao finito a aparência do infinito, eu romantizo-o" (Ameriks 2000: 227). 


\section{The Spatiality of the Wall}

As a rule, walls are spatially effective on two sides. They run between different rooms, between inside and outside, between rooms and passageways, between houses and streets, between interiors and exteriors, between city and country. Walls simultaneously enclose and exclude. Via openings, rooms on either side of a wall are linked. Windows engender connections between the rooms of the house and the street or garden, and doors establish connections between one room and the next (Schröder 2016).

Openings themselves are spaces, i.e. when they make it possible for inhabitants to abide within the wall itself: within doorways, windows, niches, and so forth. The opening reveals the thickness of the wall, which in turn stands in a proportional relationship not just -

\section{La Espacialidad del Muro}

Como regla, los muros funcionan espacialmente por los dos lados. Se disponen entre diferentes habitaciones, entre el dentro y el fuera, entre cuartos y pasillos, entre casas y calles, entre interiores y exteriores, entre ciudad y país. Los muros rodean y excluyen simultáneamente. A través de aberturas, los cuartos a ambos lados del muro quedan vinculados. Las ventanas generan conexiones entre las habitaciones de la vivienda y con la calle o el jardín, y las puertas establecen conexiones entre una habitación y la siguiente (Schröder 2016).

Los huecos son espacios en sí mismos, es decir, permiten que el usuario habite dentro del propio muro: en las puertas, ventanas, nichos, etc. La abertura revela el espesor del muro, que a su vez se
A espacialidade da parede

Em princípio, as paredes são espacialmente eficazes em dois lados. Elas fazem a ligação entre divisões diferentes, entre a parte de dentro e a parte de fora, entre quartos e passagens, entre casas e ruas, entre interiores e exteriores, entre cidade e campo. As paredes incluem e excluem ao mesmo tempo. Através de aberturas, as divisões de qualquer um dos lados de uma parede são ligadas. As janelas engendram conexões entre as divisões da casa e a rua ou o jardim, e as portas estabelecem conexões entre uma divisão e a próxima (Schröder 2016).

As aberturas são por si só espaços, isto é, quando elas possibilitam ao habitante permanecer dentro da parede: dentro de vãos de porta, janelas, nichos, e por aí adiante. A abertura revela a espessura da parede, que por sua vez tem uma rela-
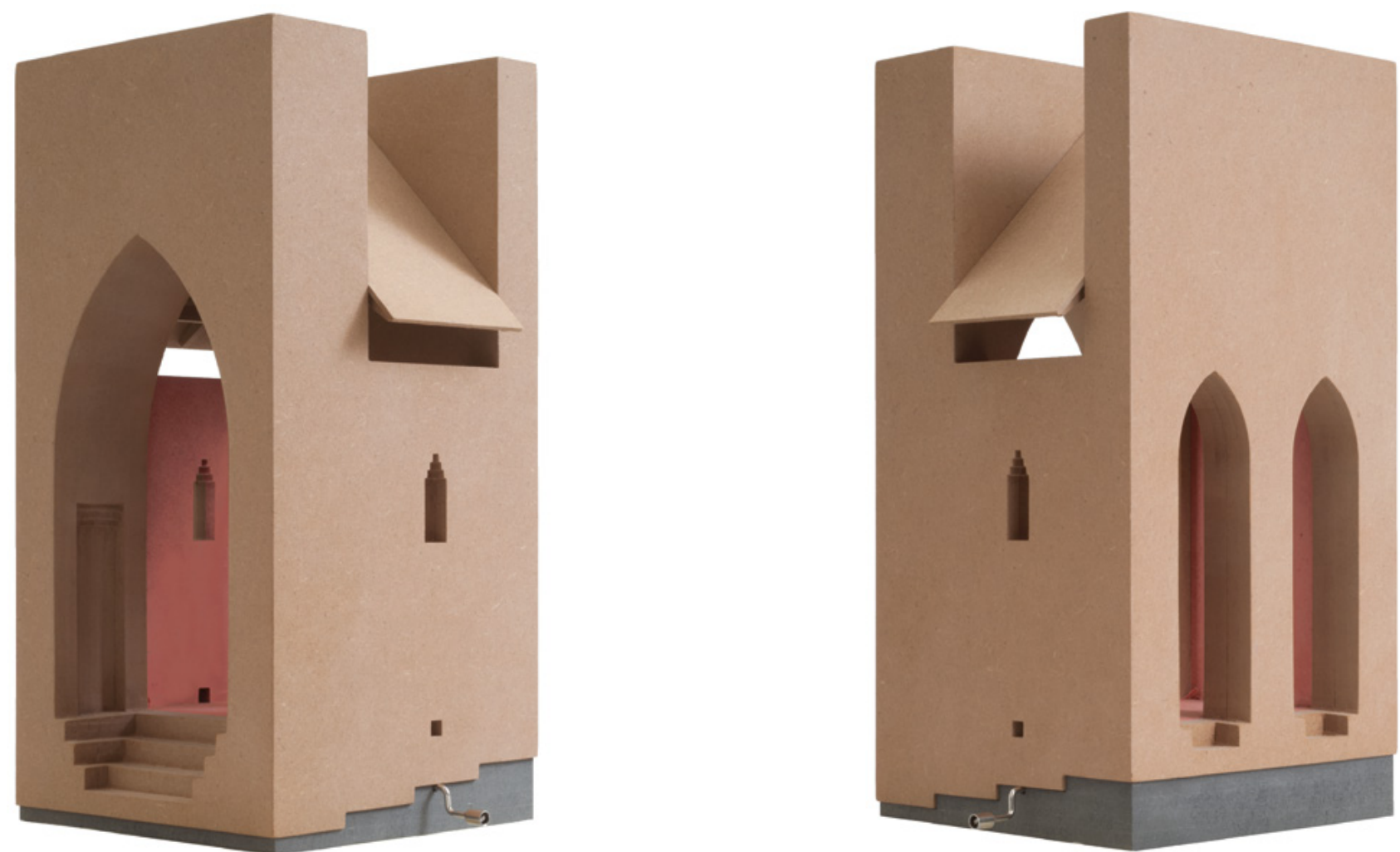

Three-dimensional model of the tower, showing its façades | Modelo tridimensional de la torre, mostrando sus fachadas | Modelo tridimensional da torre que mostra os alçados 
through the threshold, the embrasure, and the lintel - with the space of the opening itself, but in a similar fashion with adjacent rooms, whether outside or inside. It is here in particular that architecture is revealed as an art of space of boundaries and transitions.

\section{Why the Arch?}

Being incapable of anything else (at least in the absence of ancillary forms of support), brick creates arches and vaults. The openings beneath arches give walls a heavy appearance. Loads are deflected in a flowing way via the arches into walls and pillars and dissipated into the mass of the earth. This 'flow' allows the walls to be rooted in the ground, so to speak, and to grow out of it. encuentra en una relación proporcional a través del umbral, el alféizar y el dintel - no sólo con el espacio de la abertura en sí, sino que, de manera similar, con las habitaciones adyacentes, ya sea en el exterior o en el interior. Es aquí en particular donde la arquitectura se revela como el arte del espacio de las fronteras $\mathrm{y}$ transiciones.

\section{¿Por qué el Arco?}

En ausencia de formas auxiliares de soporte, el ladrillo sólo puede crear arcos y bóvedas. Los huecos bajo los arcos dan a las paredes un aspecto pesado. Las cargas se desvían de forma fluida a través de los arcos, hacia los muros y pilares, y son disipadas en la masa del terreno. Este "flujo" permite a los muros enraizarse en la tierra, por así decirlo, y crecer hacia fuera. ção proporcional não só - através do umbral, do vão, e do lintel - com o espaço da abertura propriamente dito mas, de uma forma similar, com as divisões adjacentes, tanto no exterior como no interior. É aqui em particular que a arquitectura é revelada como uma arte do espaço de fronteiras e transições.

Porquê o arco?

Sendo incapaz de algo mais (pelo menos na ausência de formas auxiliares de suporte), o tijolo cria arcos e abóbadas. As aberturas por debaixo dos arcos dão às paredes uma aparência pesada. O peso é desviado de uma forma fluída através dos arcos para as paredes e pilares, e dissipado na massa da terra. Este 'fluxo' permite às paredes enraizarem-se no chão, digamos assim, e crescer a partir dele.

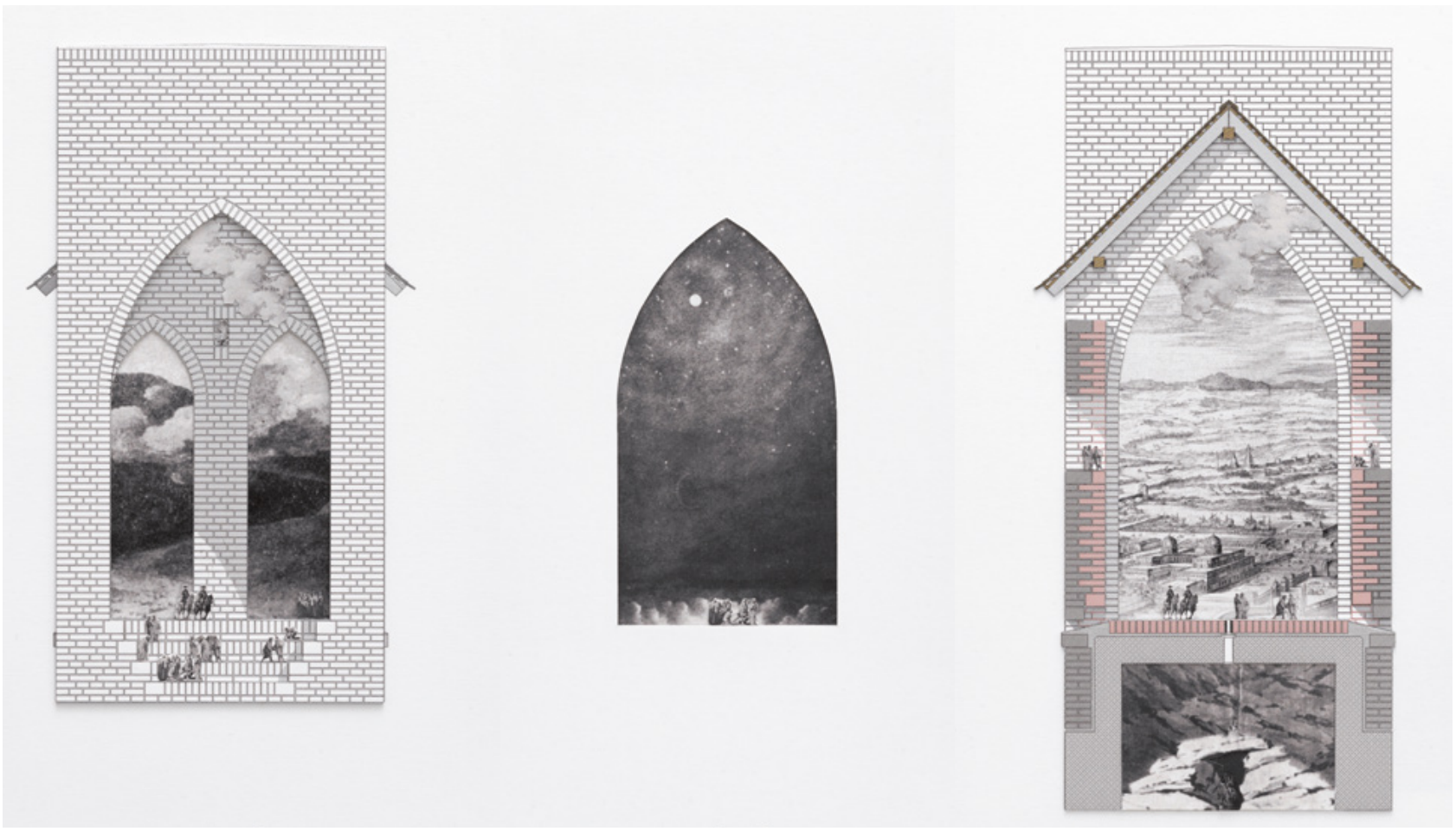



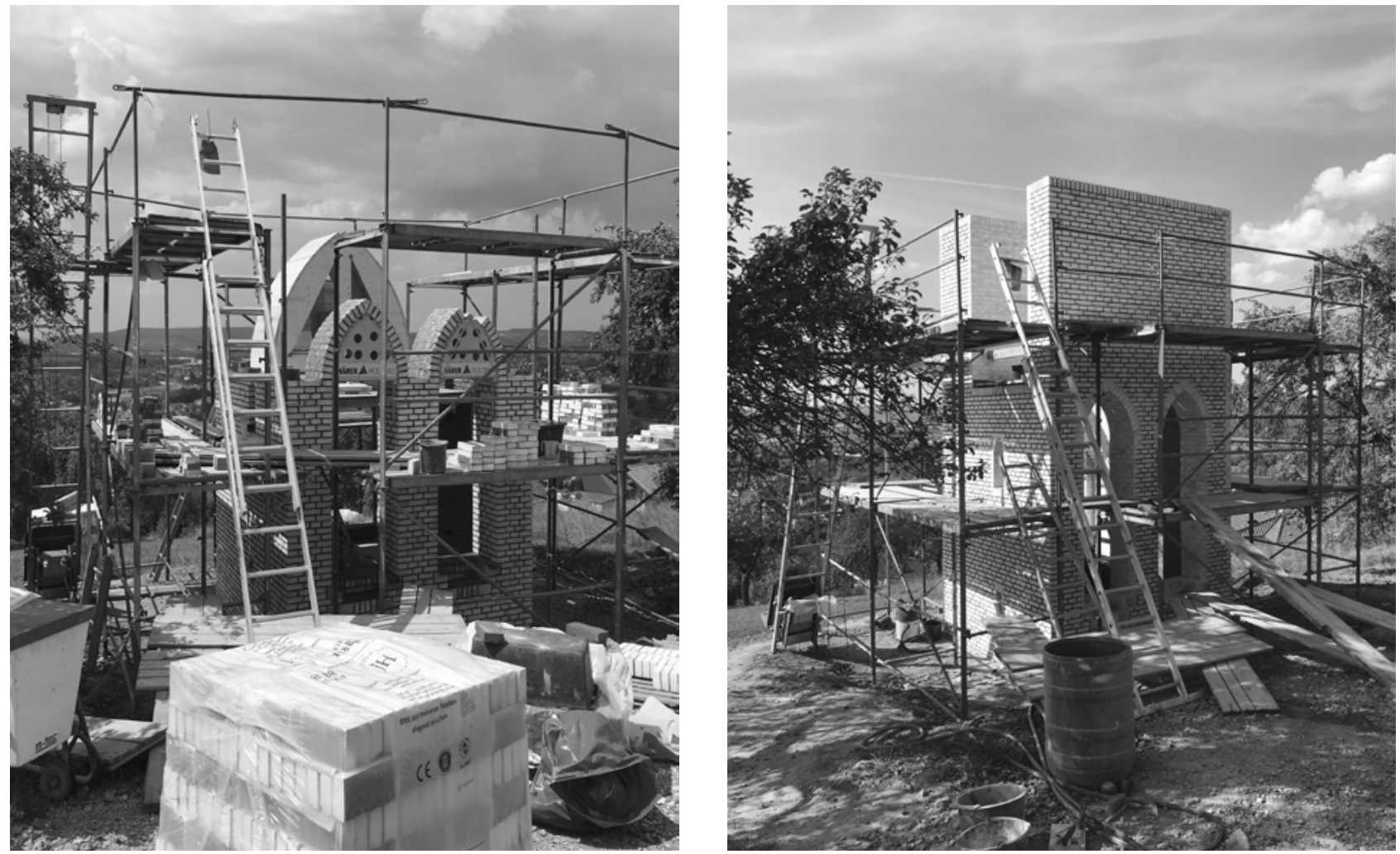

In a very particular way, arches and vaults delineate the interior spatiality of the wall: spatially, the protective and sheltering character of the enclosing and at the same time opening gesture has an intensifying effect on places and routes. An arch focuses the center, through which the gaze and movement pass. Differently than the rectangular opening, which merely slices out and subtracts from the wall, the arch seems to expand the opening, bundling it into pillars, which is arguably why the solidity of the wall seems to remain perceptible in the space of the opening.

\section{Symbolic Geometry}

To pierce the circle at the point of the support; to take up the point of support lying opposite, guiding the line to the center above; to then repeat this procedure from the other side; to bring together the lateral elements, separately, to the center; to form a unity; this is what symbolic geometry means here.
De manera muy particular, los arcos y bóvedas delimitan la espacialidad interior del muro: espacialmente, el carácter protegido y de refugio del cerco, coincidente con el gesto de apertura, tiene un efecto intensificador de los lugares y los recorridos. Un arco enfoca el centro, por donde pasan la mirada y el movimiento. A diferencia de una abertura rectangular, que simplemente se corta y se sustrae de la pared, el arco parece expandir la abertura, enmarcándola entre pilares, que es posiblemente la razón por la que la solidez del muro parece permanecer perceptible en el espacio del hueco.

\section{La Geometría Simbólica}

Perforar el círculo en el punto de apoyo, tomar el punto de apoyo opuesto, guiando la línea hacia el centro superior; y luego repetir este procedimiento desde el otro lado, juntar los elementos laterales, por separado, hacia el centro, para formar una unidad; esto es lo que significa aquí geometría simbólica.
De uma forma muito particular, os arcos e abóbadas delineiam a espacialidade interior da parede: espacialmente, o carácter protector e acolhedor do gesto que é ao mesmo tempo de inclusão e de abertura, tem o efeito de intensificar os locais e trajectos. Um arco focaliza o centro, através do qual o olhar e o movimento passam. Contrariamente à abertura rectangular, que meramente secciona e retira da parede, o arco parece expandir a abertura, agregando-a aos pilares, e é provavelmente por isto que a solidez da parede parece permanecer perceptível no espaço da abertura.

Geometria simbólica

Penetrar o círculo no ponto de suporte, partir do ponto de suporte do lado oposto, guiando a linha até ao centro acima; para depois repetir este procedimento a partir do outro lado..., para unir os segmentos laterais, separadamente, até ao centro, para formar uma unidade, é isto o que significa a geometria simbólica. 

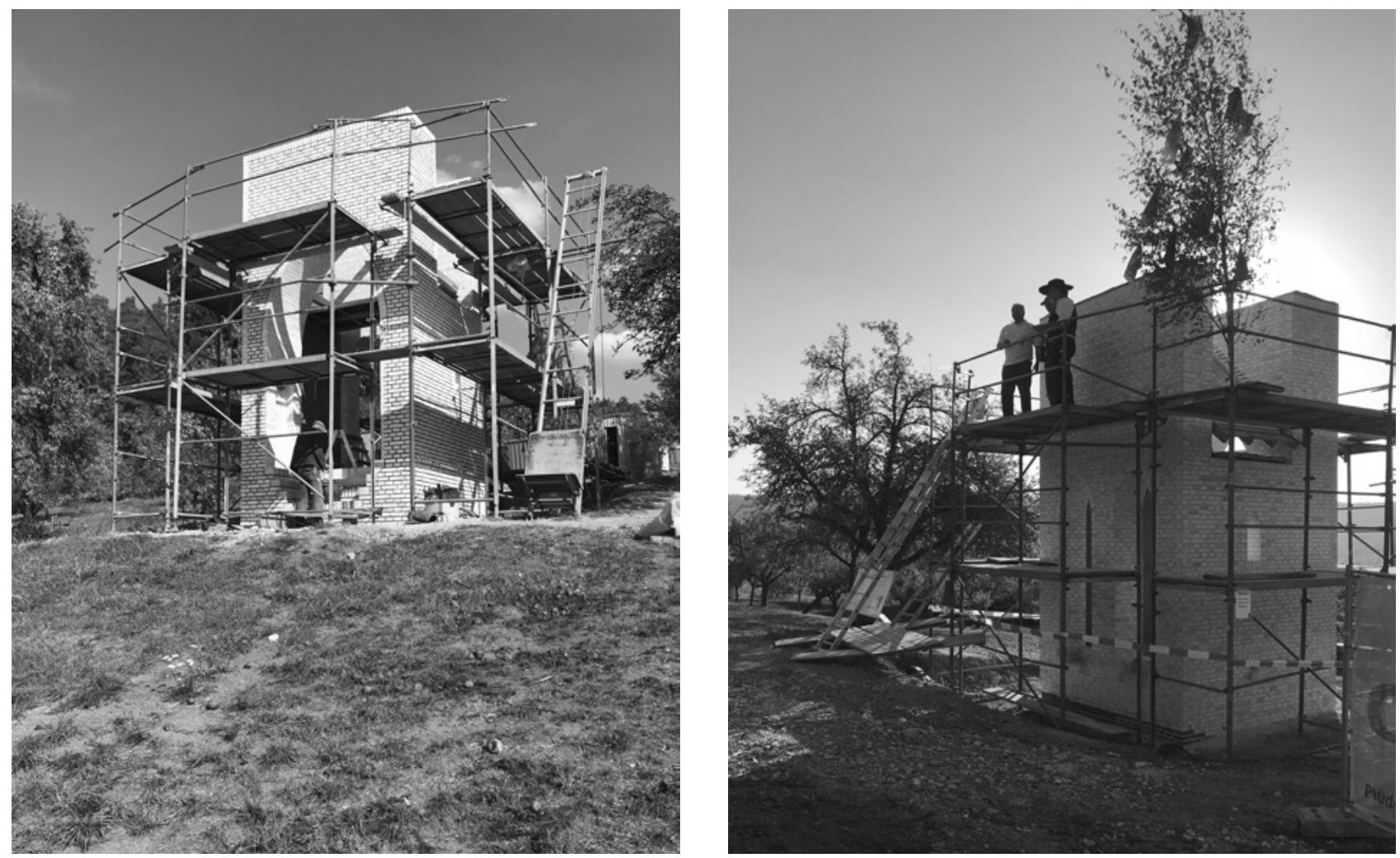

1 to 4: Photographs of the construction process of the tower with the scaffolding $\mid 1$ a 4 : Fotografías del proceso de construcción de la torre con el andamiaje 1 a 2: Fotografias do processo construtivo da torre com os andaimes

\section{The Monument}

"To the sublime in building" - claims one philosopher - "greatness of dimensions seems requisite; for on a few parts, and those small, the imagination cannot rise to any idea of infinity" (Burke 2015: 62).

Not at all. The sublime - we would counter - raises not so much the question of the sheer size of a given space, and instead that of its intention in relation to its sense of spatial and formal intensity: $3 \times 3 \times 6$ meters may prove perfectly adequate.

\section{Craft}

But let us now allow the old theoretician of cladding to have his say: "Brick appears as brick...” (Semper 1844: 219). A Parmenidean fragment that speaks not of the being of things, not of the joint or of the stone, neither of the order nor of the material. The accent here lies on the word "appear," which is to say on
El Monumento

"Para lo sublime en la construcción" afirmaba un filósofo - "la grandeza de las dimensiones parece un requisito; porque en unas pocas partes, y si son pequeñas, la imaginación no puede alcanzar ninguna idea de infinito" (Burke 2015: 62).

De ningún modo. Nosotros rebatiríamos que lo sublime no plantea tanto la cuestión del mero tamaño de un espacio dado, sino la de su intención de relacionarse con un sentido de intensidad espacial y formal: $3 \times 3 \times 6$ metros pueden resultar perfectamente adecuados.

Oficio

Pero permitamos ahora que el antiguo teórico del revestimiento exprese su opinión: "El ladrillo parece ladrillo ..." (Semper 1844: 219). Un fragmento sobre lo inmutable, que no habla del ser de las cosas, ni de la articulación, ni de la piedra, ni del orden, ni del material. El acento aquí se pone en la palabra
O Monumento

"Para o sublime na construção" - defende um filósofo - "a grandeza de dimensões parece ser um requisito; pois com apenas algumas partes, sendo elas pequenas, a imaginação não pode elevar-se a qualquer ideia de infinito" (Burke 2015: 62).

De modo algum. O sublime — podemos contra-argumentar - levanta não tanto a questão do mero tamanho de um determinado espaço, mas sim a da sua intenção em relação ao seu sentimento de intensidade espacial e formal: 3 x 3 x 6 metros pode revelar-se perfeitamente adequado...

Ofício

Mas deixemos agora o velho teórico do revestimento ter uma palavra a dizer: “Tijolo aparece como tijolo..." (Semper 1844: 219). Um fragmento parmenidiano que não fala sobre o ser das coisas, da junta ou da pedra, nem da ordem ou do material. Aqui o ênfase assenta na palavra "aparecer", que é como quem diz no 


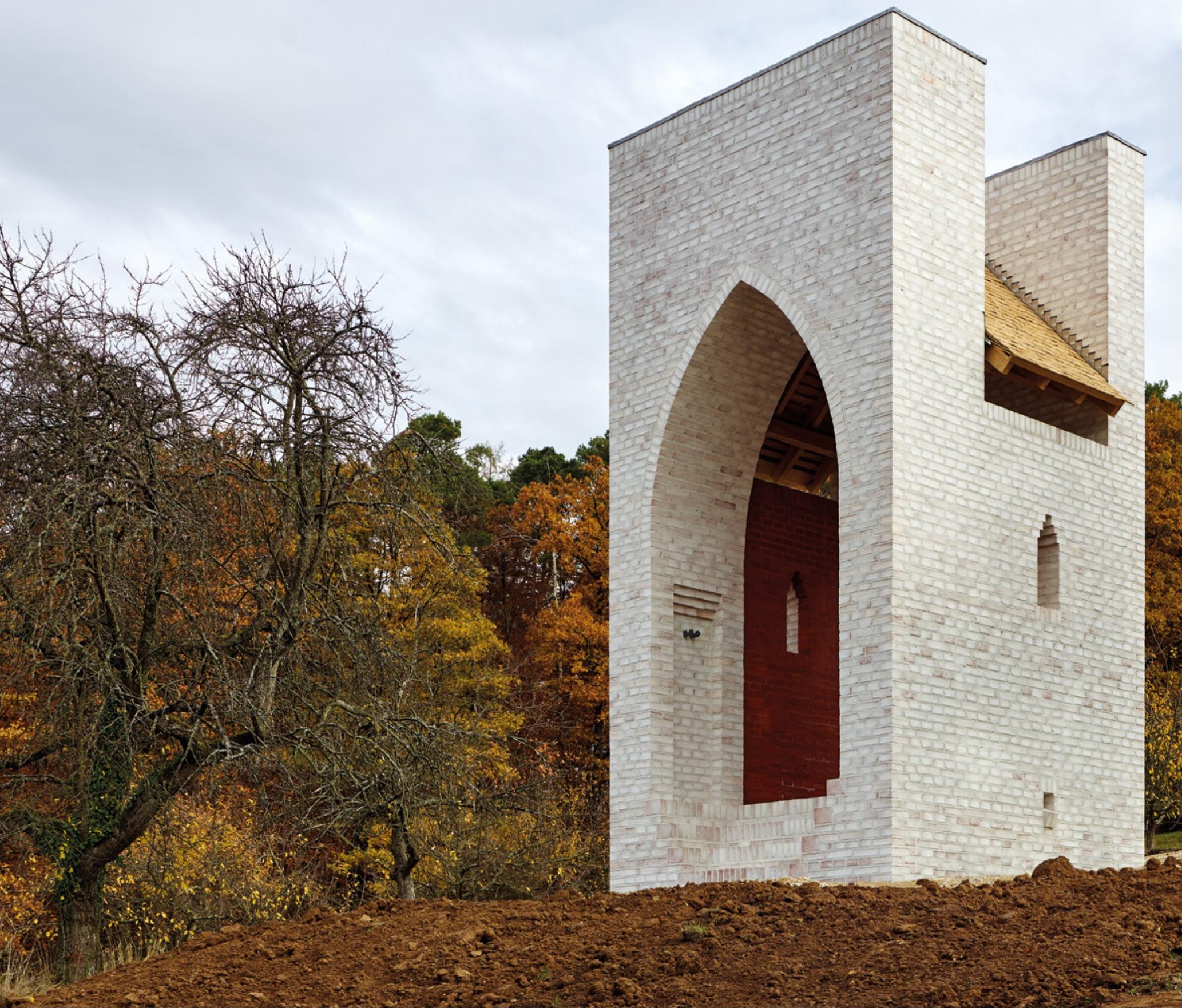

its reflection in the eye of the beholder, on presentation and perception, on the proportionality to which we refer as scale.

\section{The Building}

Required before a space as such is able to appear is its form, its material form, as floor, wall, and roof. The form does not however precede the space; enjoying precedence, always, is the idea of the "parecer", es decir, en su reflejo en el ojo del espectador, en la presentación y la percepción, sobre la proporcionalidad que llamamos escala.

\section{EI Edificio}

Para que un espacio como tal pueda mostrarse en su forma, requiere de sus elementos materiales, como suelo, pared y techo. La forma, sin embargo, no precede al espacio; la idea del espacio siempre seu reflexo sobre o olhar do observador, na apresentação e percepção, na proporcionalidade à qual nos referimos como escala.

O edificio

Necessário antes que um espaço como tal possa surgir na sua forma, na sua forma material como piso, parede e teto. No entanto, a forma não precede o espaço; $\mathrm{o}$ que beneficia da precedência é, sempre, a 
space. Architectural space is dependent upon architectural form, while nonetheless, the form is only an emblem, only a symbol of the space. The form is only the form of the space, just as the space is only the space of dwelling. The form (matrix) presents itself therefore as the imprint (patrix) of the space, on the inside as well as on the outside, and the space in contrast as the imprint of a purpose. la precede. El espacio arquitectónico depende de la forma arquitectónica, mientras que, sin embargo, la forma es sólo un emblema, sólo un símbolo del espacio. La forma es sólo la forma del espacio, así como el espacio es sólo el espacio de la vivienda. La forma (matrix) se presenta, así pues, como la huella (patrix) del espacio, tanto en el interior como en el exterior, mientras el espacio, en contraste, se presenta como la huella de un propósito.

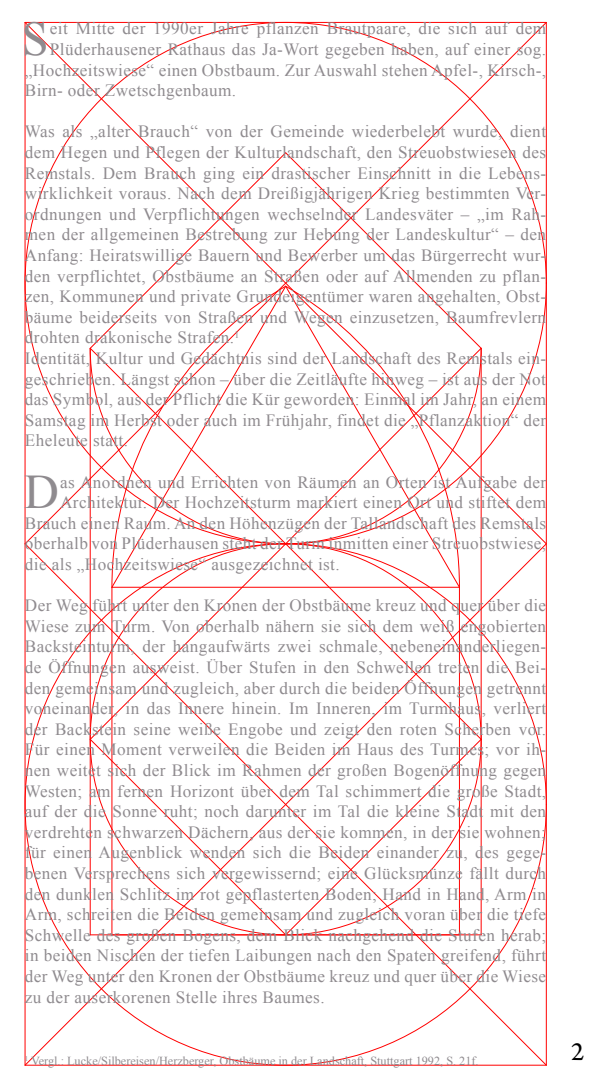

1: Exterior view of the tower after its completion 2: Geometric design of the tower |1: Vista exterior de la torre tras su conclusión 2: Trazado geométrico de la torre |1: Vista exterior da torre após a sua conclusão 2: Traçado geométrico da torre (1: Stefan Müller Berlin)

ideia do espaço. $\mathrm{O}$ espaço arquitectónico depende da forma arquitectónica. Apesar disso, a forma é apenas um emblema, apenas um símbolo do espaço. A forma é apenas a forma do espaço, assim como o espaço é apenas o espaço da habitação. A forma (matrix) apresenta-se assim como a impressão (patrix) do espaço, tanto no interior como no exterior, e o espaço, em contraste, como a impressão de um propósito. 


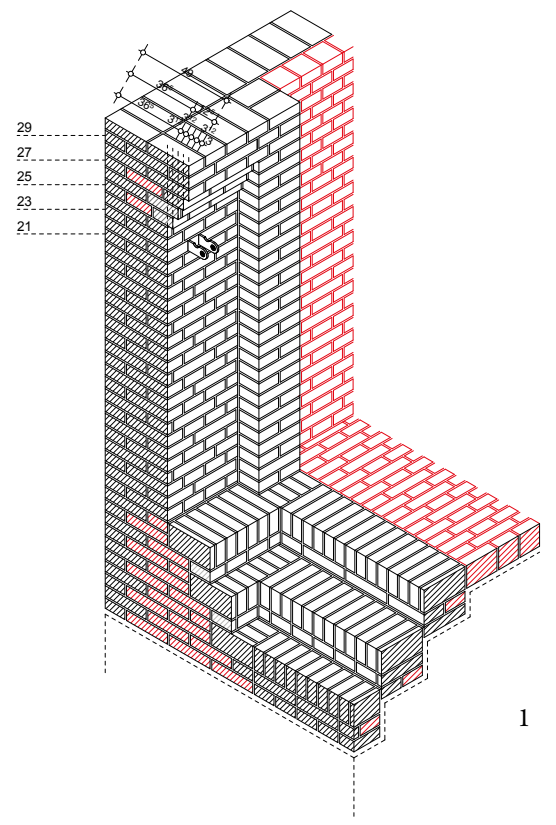

\section{Conclusion}

In closing, finally, an excerpt from my brief address on the occasion of the recent roofing ceremony on the "Hochzeitswies," adapted here, of course, to today's event, as is often the case: "There, it quickly became clear: a space for this custom; established as the sanctum; erected here as a tower; ... of which we speak this hour..."

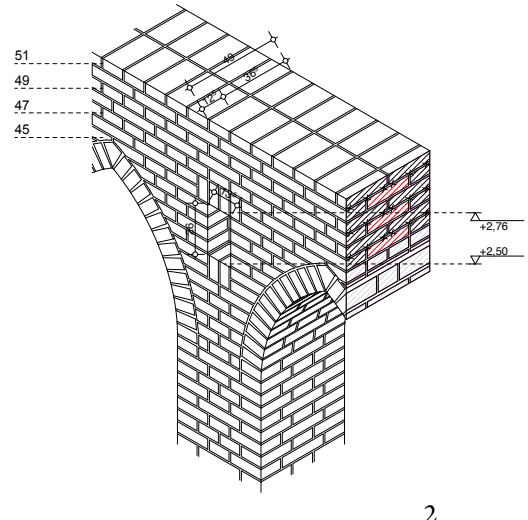

Conclusion

Para terminar, finalmente, un extracto de mi breve discurso con motivo de la reciente ceremonia de coronación celebrada en el "Hochzeitswies", adaptado aquí, por supuesto, al evento de hoy, como a menudo es el caso: "Allí, rápidamente quedó claro: un espacio para esta costumbre; establecido como el santuario; erigido aquí como una torre; del cual hablamos en esta hora...”

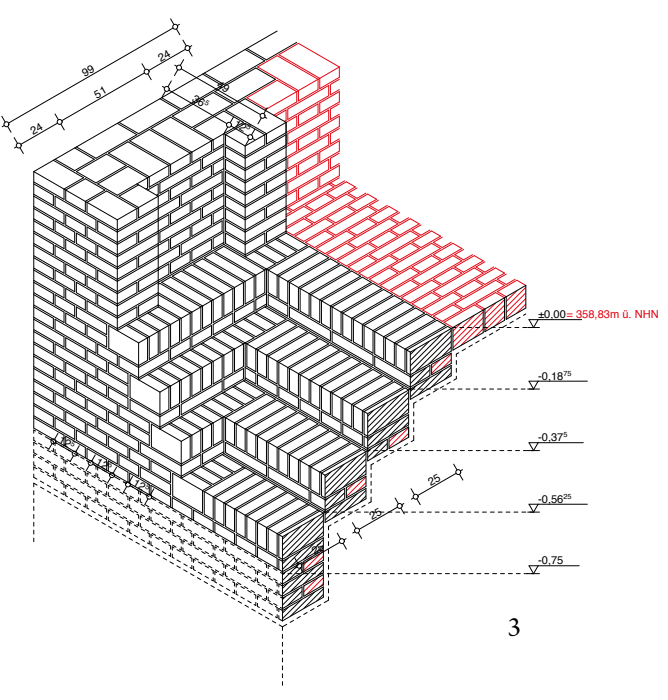

Conclusão

Em suma, por fim, um excerto do meu breve discurso pela ocasião da recente cerimónia de conclusão do edifício no "Hochzeitswies", adaptado aqui, certamente, ao acontecimento de hoje, como é frequentemente o caso: "Ali, tornou-se prontamente claro: um espaço para este costume; estabelecido como o santuário; erigido aqui como uma torre; ... da qual falamos neste momento..."

Ameriks, Karl (ed.). 2000. The Cambridge Companion to German Idealism, Cambridge: Cambridge University Press. Burke, Edmund. [1757] 2015. A Philosophical Enquiry into the Sublime and Beautiful. Oxford: Oxford University Press. Schröder, Uwe. 2016. Die Wand. Grenze der Architektur - Architektur der Grenze. der architekt, 4/16.

Semper, Gottfried. 1884. Vorläufige Bemerkungen über bemalte Architektur und Plastik bei den Alten (Altona 1834). In: Semper, Manfred; and Semper, Hans (Ed.), Kleine Schriften, Berlin/Stuttgart: W. Spemann

\section{Uwe Schröder}

He studied architecture at the Rheinisch-Westfälische Technische Hochschule Aachen (RWTH) and the Kunstakademie Düsseldorf. Since 1993, he has maintained his own office in Bonn. After teaching positions in Bochum and Cologne, he was a professor of design and architectural theory at the Cologne University of Applied Sciences (TH Köln) from 2004 to 2008, and has been a professor at the Department of Spatial Design at the Faculty of Architecture of the RWTH Aachen since 2008. He was a Guest Professor at the Università di Bologna (2009-2010), at the Università degli Studi di Napoli (2016), at the Politecnico di Bari (2016), at the Università degli Studi di Catania (2018) and at the Politecnico di Milano (2018-2019).

Estudió arquitectura en la Rheinisch-Westfälische Technische Hochschule Aachen (RWTH) y en la Kunstakademie Düsseldorf. Desde 1993, ha mantenido su propio despacho en Bonn. Después de enseñar en Bochum y Colonia, fue profesor de diseño y teoría de la arquitectura en la Universidad de Ciencias Aplicadas de Colonia (TH Köln) desde 2004 hasta 2008, y ha sido profesor en el Departamento de Diseño Espacial de la Facultad de Arquitectura de la RWTH Aachen desde 2008. Fue profesor invitado en la Università di Bologna (2009-2010), en la Università degli Studi di Napoli (2016), en el Politécnico di Bari (2016), en la Università degli Studi di Catania (2018) y en el Politécnico di Milano (2018-2019).

Estudou arquitectura no Rheinisch-Westfälische Technische Hochschule Aachen (RWTH) e na Kunstakademie Düsseldorf. Desde 1993, manteve o seu próprio escritório em Bona. Após leccionar em Bochum e Cologne, foi professor de design e teoria arquitectónica na TH Köln entre 2004 e 2008 , e foi professor no Department of Spatial Design da Faculty of Architecture na RWTH Aachen desde 2008. Foi professor convidado na Università di Bologna (2009-2010), na Università degli Studi di Napoli (2016), no Politecnico di Bari (2016), na Università degli Studi di Catania (2018) e no Politecnico di Milano (2018-2019).

This text has been previously published in | Este texto ha sido previamente publicado en | Este texto foi publicado anteriormente em: Divisare; Archello; Neri, Raffaella (Ed.). 2019. Uwe Schröder. Il paesaggio della torre / The landscape of the tower. Milán: Maggioli Editore; and Schröder, Uwe. 2019. La Historia de la Torre en el Rio Rems en 12 capítulos/ The Story of the Tower on the Rems in 12 chapters. DPArquitectura, XXV, 34-45. 


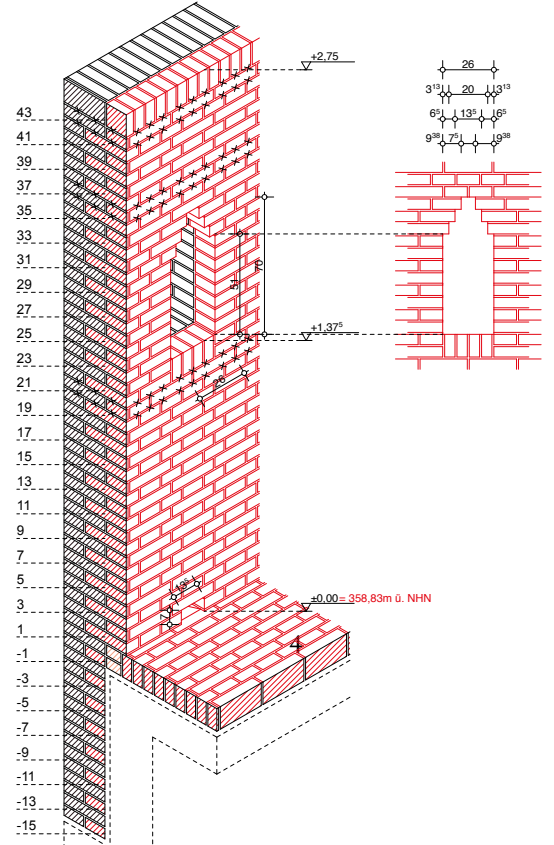

5

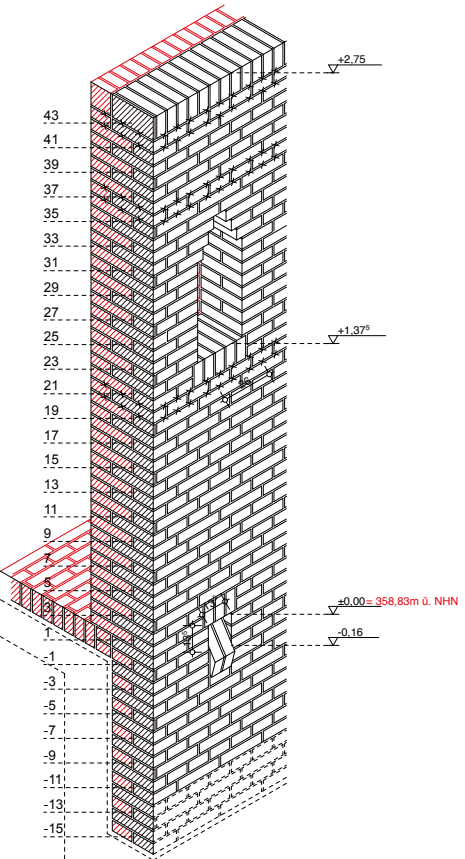

1 to 5: Construction details of the brick walls and arches 6: View of the interior of the tower, with its timber roof 1 a 5: Detalles constructivos de los muros y arcos de ladrillo 6: Vista del interior de la torre, con su cubierta de madera 1 a 5: Pormenores construtivos dos muros e arcos em tijolo 6: Vista do interior da torre, com a cobertura em madeira (6:Stefan Müller Berlin)

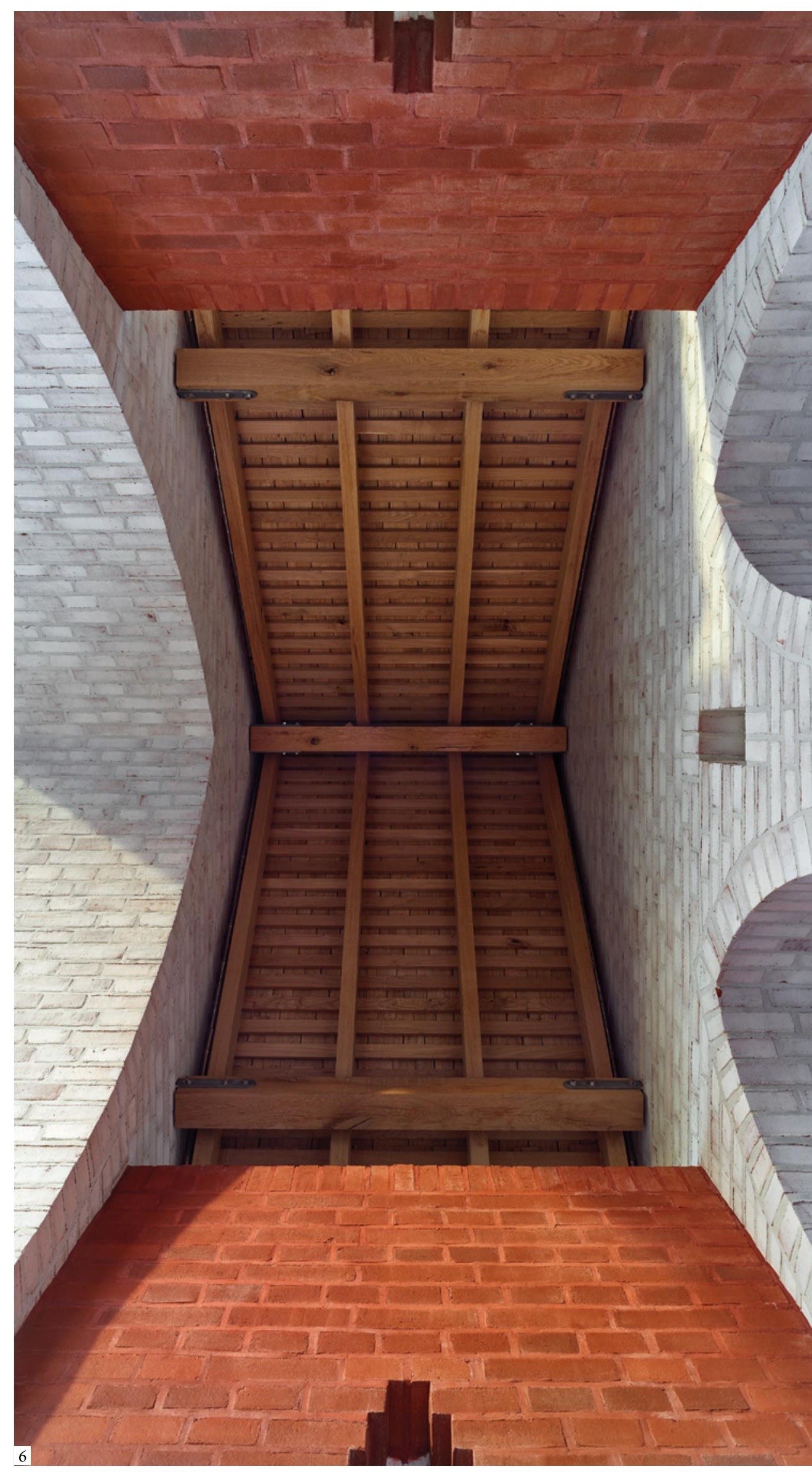

